\title{
Jatropha production in function of organic fertilization with cassava water and cow urine
}

\section{Fábio Agra de Medeiros Nápoles ${ }^{1}$, José Thyago Aires Souza ${ }^{2}$, Carlos Alberto Vieira de Azevedo $^{3}$, Giliane Aparecida Vicente da Silva Souza ${ }^{2}$, Denizard Oresca ${ }^{4}$, Suenildo Josemo Costa Oliveira ${ }^{1}$}

\author{
${ }^{1}$ Universidade Estadual da Paraíba, Campus Lagoa Seca, Lagoa Seca, Paraíba, Brasil. E-mail: fnapoles@uol.com.br, \\ suenildo@ccaa.uepb.edu.br \\ ${ }^{2}$ Universidade Federal da Paraíba, Campus Areia, Areia, Paraíba, Brasil. E-mail: thyago.agro@ @otmail.com, \\ gilianeagroecologia@hotmail.com \\ ${ }^{3}$ Universidade Federal de Campina Grande, Campina Grande-PB, Brasil. E-mail: cazevedo@ deag.ufcg.edu.br \\ ${ }^{4}$ Universidade Federal de Pernambuco, Recife, Pernambuco, Brasil. E-mail: orescad@gmail.com
}

Recebido: 17/07/2017; Aceito: 11/01/2018.

\section{RESUMO}

The objective of this study was to evaluate the production of jatropha (Jatropha curcas L.) submitted to fertilization with cow urine and cassava water. The experiment was conducted under field conditions in the municipality of Lagoa Seca, Paraíba State, Brazil. A 5 x 5 factorial scheme was used in a randomized complete block design with 25 treatments and 4 replicates, using different volumes of cow urine and cassava water. Irrigation was performed twice a week corresponding to $100 \%$ of ET0, where all plants received the same water blade. The syrup with $750 \mathrm{~mL}$ of cassava water and $750 \mathrm{~mL}$ of cow urine provided a greater number of fruits (33.00); however, the larger green mass of the fruits $(224.59 \mathrm{~g})$ was obtained when cow urine was added into $1,000 \mathrm{~mL}$ of cassava water. The dry weight of the fruits obtained the lowest value (48.92 $\mathrm{g}$ ), when $250 \mathrm{~mL}$ of cow urine was used in the absence of cassava water. The cow urine and cassava water increase production and weight of the fruit of jatropha, which can be used as organic fertilizer for the crop.

Palavras-chave: Oleaginous, biofertilizers, agroecology.

\section{Produção de pinhão manso em função de adubação orgânica com manipueira e urina de vaca}

\begin{abstract}
Objetivou-se com este trabalho avaliar a produção do pinhão manso (Jatropha curcas L.) submetido a adubação com urina de vaca e manipueira. O experimento foi desenvolvido em condições de campo, no município de Lagoa Seca, estado da Paraíba. Utilizou-se esquema fatorial 5 x 5, em delineamento experimental de blocos ao acaso com 25 tratamentos e 4 repetições, utilizando diferentes volumes de calda de urina de vaca e manipueira. A irrigação foi realizada duas vezes por semana correspondendo a $100 \%$ da $\mathrm{ET}_{0}$, onde todas as plantas receberam a mesma lâmina de água. A calda com $750 \mathrm{~mL}$ de manipueira e $750 \mathrm{~mL}$ de urina de vaca proporcionou maior número de frutos $(33,00)$, entretanto, a maior massa verde dos frutos, $(224,59 \mathrm{~g})$ foi obtida quando se acrescentou urina de vaca dentro de $1000 \mathrm{ml}$ da calda com manipueira. O peso seco dos frutos obteve o menor valor (48,92 g), quando se utilizou $250 \mathrm{ml}$ de urina de vaca na ausência de manipueira. A urina de vaca e a manipueira elevam a produção e o peso dos frutos de pinhão manso, podendo ser utilizadas como adubação orgânica para a cultura.
\end{abstract}

Key words: Oleaginosa, biofertilizantes, agroecologia. 


\section{Introduction}

Jatropha curcas L. belongs to the family Euphorbiaceae, and a species with ample agricultural potential, standing out for the productivity and satisfactory quality of the oil, aiming at the production of biodiesel. This species has aroused commercial interest in Brazil and throughout the world, as it presents desirable characteristics both in the renewal of the national energy base and in family agriculture, favoring the permanence of the man in the field (DALLACORT et al., 2010; GARRONE et al., 2016).

The jatropha is being considered quite a while more advantageous agricultural option for the Northeast of Brazil, is dealing with demanding species insolation and strong resistance to drought (OLIVEIRA et al., 2010). According to Drumond et al. (2010), this oilseed produces an average of $330 \mathrm{~kg} \mathrm{ha}^{-1}$ of seed, under dry conditions and $1.200 \mathrm{~kg} \mathrm{ha}^{-1}$ in irrigated area in the first year of production.

Cow urine can be considered a sub-product of livestock activity, and is widely available on many rural properties. Because it is rich in minerals, it is thought to provide nutrients and other beneficial substances to plants at a reduced cost; in addition, its use does not cause risk to the health of producers and consumers, being practically ready for use, simply adding water (CELESTINO, 2002; NÁPOLES et al., 2016).

The cassava water is characterized as a liquid extract of milky-looking and light-yellow color originated from the processing of cassava roots having a strong acid odor containing 5 to $7 \%$ of starch, glucose, hydrocyanic acid and other organic substances (carbohydrates, proteins and lipids) and mineral nutrients (FIORETTO, 2002). The cassava water has immense potential as fertilizer in agriculture because it presents nutrient contents, mainly nitrogen and potassium (MAGALHÃES et al., 2014).

The use of organic fertilizers such as cow urine and cassava water are of paramount importance for the development of agriculture in the current world conditions, due to the excess of agrochemicals used in the crops, which can be used as fertilizers or agricultural pesticides, still avoiding the contamination of natural resources due to excess of agrochemicals in the environment.

In this context, this study aims to evaluate the production of the jatropha submitted to organic fertilization with cow urine and cassava water.

\section{Material and Methods}

The experiment was carried out under field conditions at the Center of Agrarian and Environmental Sciences (CCAA), Campus II of the State University of Paraiba (UEPB), Lagoa Seca, Paraíba, Brazil (latitude $7^{\circ} 09^{\prime} \mathrm{S}$; longitude $35^{\circ} 52^{\prime} \mathrm{W}$ and altitude of $634 \mathrm{~m}$. The soil of the experimental area was classified as an Neossolo Regolítico Eutrófico (Embrapa, 2013), nonsaline, moderately sloping, deep, sandy loam textural class with good drainage and moderate fertility, as regards salinity is classified as normal Table 1). Cow urine was collected from dairy cows in the region and the cassava water was obtained from flour houses near the experimental area. Samples of cow urine and cassava water were also collected for chemical characterization (Table 2)

Table 1. Chemical and soil fertility attributes in the 0-20 and $21-40 \mathrm{~cm}$ layers

\begin{tabular}{lccc}
\hline \multicolumn{1}{c}{$\begin{array}{c}\text { Chemical } \\
\text { characteristic }\end{array}$} & Unit & $\begin{array}{c}\text { Depth } \\
(0-20 \mathrm{~cm})\end{array}$ & $\begin{array}{c}\text { Depth } \\
(20-40 \mathrm{~cm})\end{array}$ \\
\hline $\mathrm{pH}$ in water (1:2.5) & - & 5.6 & 5.38 \\
$\mathrm{P}$ & $\mathrm{mg} \mathrm{dm}^{-3}$ & 15.21 & 4.76 \\
$\mathrm{~S}_{\mathrm{SO}}{ }_{4}^{-2}$ & $\mathrm{mg} \mathrm{dm}^{-3}$ & $<\mathrm{LDA}$ & 5.26 \\
$\mathrm{~K}^{+}$ & $\mathrm{mg} \mathrm{dm}^{-3}$ & 114 & 72 \\
$\mathrm{Na}^{+}$ & $\mathrm{cmol}_{\mathrm{c}} \mathrm{dm}^{-3}$ & 0.27 & 0.19 \\
$\mathrm{H}^{+}+\mathrm{Al}^{+3}$ & $\mathrm{cmol}_{\mathrm{c}} \mathrm{dm}^{-3}$ & 4.46 & 5.36 \\
$\mathrm{Al}^{+3}$ & $\mathrm{cmol}_{\mathrm{c}} \mathrm{dm}^{-3}$ & 0.05 & 0.20 \\
$\mathrm{Ca}^{+2}$ & $\mathrm{cmol}_{\mathrm{c}} \mathrm{dm}^{-3}$ & 2.40 & 1.85 \\
$\mathrm{Mg}^{+2}$ & $\mathrm{cmol}_{\mathrm{c}} \mathrm{dm}^{-3}$ & 1.10 & 0.85 \\
$\mathrm{SB}$ & - & 3.81 & 3.07 \\
$\mathrm{CEC}$ & - & 8.27 & 8.43 \\
$\mathrm{O} . \mathrm{M}$. & - & 10.14 \\
$\mathrm{Fe}$ & $\mathrm{g} \mathrm{kg}^{-1}$ & 12.55 & 5.48 \\
$\mathrm{Mn}$ & $\mathrm{mg} \mathrm{dm}^{-3}$ & 5.04 & 15.33 \\
$\mathrm{Zn}$ & $\mathrm{mg} \mathrm{dm}^{-3}$ & 19.32 & 0.66 \\
\hline
\end{tabular}

Table 2. Physical and chemical composition of cow urine and cassava used in the research.

\begin{tabular}{lcccc}
\hline Parameter & PU & DU (10\%) & PC & Dc (50\%) \\
\hline $\mathrm{pH}$ & 8.34 & 7.81 & 4.5 & 4.47 \\
$\mathrm{P}(\mathrm{mg} \mathrm{P} / \mathrm{L})$ & 41.5 & 20.37 & 273 & 139.35 \\
$\mathrm{~N}(\mathrm{mg} \mathrm{N} / \mathrm{L})$ & 2.609 & 100.8 & 2.049 & 636.2 \\
$\mathrm{Cl}(\mathrm{mg} \mathrm{Cl} / \mathrm{L})$ & - & - & - & - \\
$\mathrm{Ce}(\mathrm{mS} / \mathrm{cm})$ & 5.6 & 1.13 & 8.43 & 7.95 \\
$\mathrm{DQO}\left(\mathrm{mg} \mathrm{O}_{2} / \mathrm{L}\right)$ & 12.59 & 956 & 141.03 & 71.71
\end{tabular}

$\mathrm{P}=$ Phosphorus; $\mathrm{N}=$ Nitrogen; $\mathrm{Cl}=$ Chloride; $\mathrm{Ce}=$ Condutivity electrical; UP = Pure Urine; UD = Dilute Urine $(10 \%) ; \mathrm{MP}=$ Pure cassava; $\mathrm{MD}=$ Diluted cassava $(50 \%)$

The variables studied were: number of fruits, mature fruit mass, dry fruit mass and oil content in Jatropha curcas L. in function of increasing doses of cow urine and different proportions of cow urine with the cassava water.

In the production of the seedlings, seeds from the Agricultural Research Company of Minas Gerais (EPAGRI-MG) were used, which were sown in polyethylene bags $(10 \mathrm{~cm}$ in diameter $\mathrm{x} 15 \mathrm{~cm}$ in height), containing substrate composed of two parts of Soil and one of earthworm humus. While the plants germinated and grew, the pits were marked $(40 \times 40 \mathrm{x}$ $40 \mathrm{~cm}$ ), opened and fertilized with $5 \mathrm{~kg}$ of bovine manure. 
Was used in the experiment, the factorial analysis of $5 \times 5$, in an experimental design of randomized blocks with 25 treatments and 4 replicates per treatment, divided into four blocks. Treatment 1 represented the control, not submitting to the application of cow urine and cassava water. In the treatments $2,3,4$ and 5 were used 250, 500, 750 and $1000 \mathrm{~mL}$ of the syrup with the cassava water, respectively, and the cow's urine was not applied. In the treatments T6 to T10, the fixed volumes of the syrup with $250 \mathrm{~mL}$ of cow urine were used, while the same sequence was followed in relation to the cassava water: $0,250,500,750$ and $1000 \mathrm{~mL}$ of syrup respectively. In the treatments $\mathrm{T} 11$ to $\mathrm{T} 15$, the fixed volume of the syrup with cow urine was $500 \mathrm{~mL}$, and again the same application sequence of the syrup with cassava: $0,250,500,750$ and $1000 \mathrm{~mL}$ respectively. In treatments $\mathrm{T} 16$ to $\mathrm{T} 20$, the fixed volume of the urine cow syrup was $750 \mathrm{~mL}$ and the amount of cassava water followed the same growing sequence above. The treatments T21, T22, T23, T24 and T25 contained 1000 $\mathrm{ml}$ of the syrup with cow urine and 0, 250, 500, 750 and $1000 \mathrm{~mL}$ of the syrup with cassava water respectively.

Irrigations were managed and controlled using a spreadsheet, where the first irrigation increased soil moisture up to field capacity (CC), and from there, the other irrigations were started. The volumes of the next irrigations varied according to the determination of the reference evapotranspiration of the climatological water balance, determined by the indirect method of Penman (1956) and by Allen et al. (1998), and performed twice a week corresponding to $100 \%$ of ETo, where all plants received the same blade of water.

The data were tabulated and submitted to analysis of variance, using SAS software (Statistical Analysis System, version 9.3, 2011), being interpreted quantitatively and qualitatively. When a significant effect was found in the analysis of variance, the regression analysis was used to determine the mathematical model. To choose the best regression model, the following criteria were adopted in order of importance: significant regression, coefficient of determination $\left(\mathrm{R}^{2}\right)$ and biological explanation in agreement with the statistical model.

\section{Results and Discussion}

For the variable, number of fruits, the highest average result was 22.35 fruits, value reached when applying the $250 \mathrm{ml}$ volume of the syrup with cow urine, being $46.55 \%$ higher than the value of the treatment that did not receive the application of the syrup to cow urine, which was 15.25 fruits (Figure 1A). As regards the weight of the mature fruits in function of increasing doses of cow urine (Figure $1 \mathrm{~B})$, the highest value was $143.62 \mathrm{~g}$, obtained in the treatment that did not receive the syrup with cow urine, being $46.17 \%$ higher than Treatment which received $1000 \mathrm{~mL}$ of the urine-cow syrup which was $98.25 \mathrm{~g}$.

Regarding the variable dry weight of the fruits, the highest average value was $59.87 \mathrm{~g}$, when using $1000 \mathrm{~mL}$ of the syrup with cow urine, representing an increase of $47.57 \%$, in relation to treatments that did not receive the application of the syrup with cow urine, with a mean value of $40.57 \mathrm{~g}$, showing a quadratic tendency to increase the dry weight of the fruits (Figure 1C).

Cesar et al. (2007) applying bovine urine in the form of spray, concluded that it promotes stimuli to the development of cucumber seedlings, regarding the development of hypocotyl, cotyledonary area and dry biomass and the maximum response to urine was observed in the concentration of $20 \%$.

In the study of the regression analysis, due to the addition of cow urine (UV), in the different volumes of the syrup with cassava water $(\mathrm{CW})$, the variable number of fruits had significant effects. The trend lines were quadratic (Figures $2 \mathrm{~A}$ and $2 \mathrm{~B}$ ) and cubic (Figure 2C), but the best result was when $750 \mathrm{~mL}$ of the cow urine (CU) was added to $750 \mathrm{~mL}$ of the cassava water (CW) (Figure 2C).

In this way, Figure $2 \mathrm{C}$ represents the highest value of production of Jatropha fruits as a function of the addition of cow urine within $750 \mathrm{~mL}$ of the syrup with cassava water, reaching 33.00 units, presenting an increase of $325.80 \%$ in relation to the lowest value of 7.75 units, obtained when only the syrup with cassava water was used.

Naples et al. (2016) observed that the dosage of $500 \mathrm{~mL}$ of cow urine in association with $500 \mathrm{~mL}$ of cassava water increases the number of fruits, however with $1000 \mathrm{~mL}$ of cassava water; it allows greater weight of mature and dry fruit of the Jatropha in the semi-arid region of Brazil.

In the study of the regression analysis as a function of the addition of cow urine, in the different volumes of the cassava water syrup, the variable, mature fruit weight (Figure 3) presented significant effects. The trend lines were quadratic (Figures 3A, 3B, 3C and 3E) and linear (Figure 3D), and the best result was obtained when $750 \mathrm{~mL}$ of the cow urine within $1000 \mathrm{~mL}$ of the cassava water syrup (Figure 4E).

Saraiva et al (2007) verified with the maize crop in a protected environment that, when the cassava wastewater was used, nutrient contents in the soil were elevated and corn growth was significant. Fernandes et al. (2013) observed that the highest averages of the production variables were verified in organically fertilized plants, especially organic compost and bovine manure. 

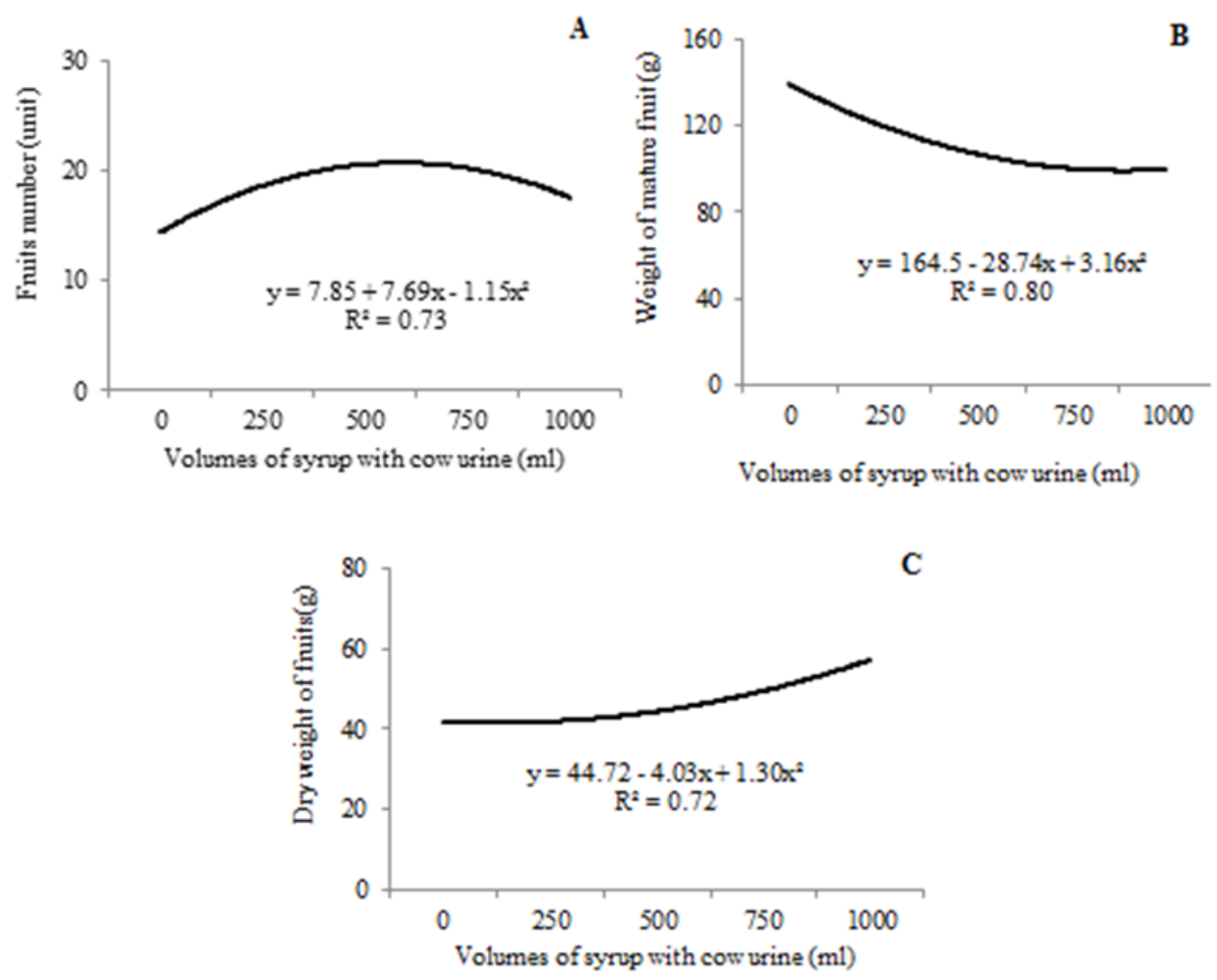

Figure 1. Regression analysis of fruit number (A), weight of mature fruit (B) and dry weight of fruit (C) of Jatropha curcas, in function of the volumes of the syrup with cow urine $(p<0.05 \mathrm{Ep}<0.01)$.

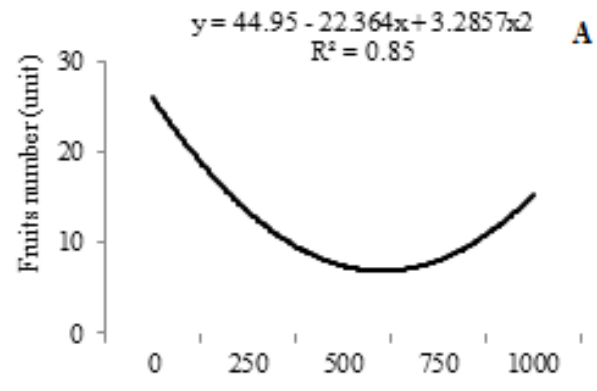

Volumes of syrup with cow urine $(\mathrm{ml})$

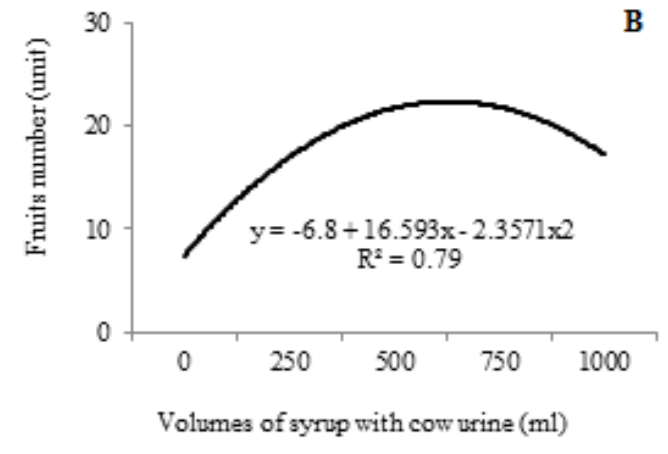

C

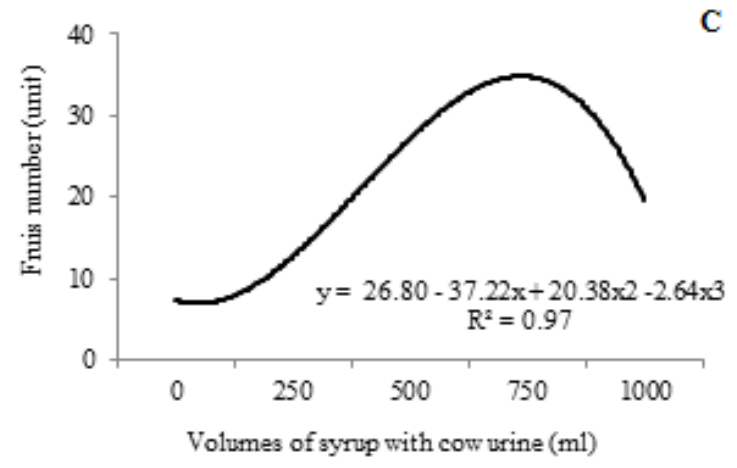

Figure 2. Regression analysis of the number of jatropha fruits during the 360 days, for interaction between cow urine within the volumes $250 \mathrm{~mL}(\mathrm{~A}), 500 \mathrm{~mL}$ (B) and $750 \mathrm{~mL}$ (C) of the syrup with cassava water ( $\mathrm{p}<0.05$ and $\mathrm{p}<0.01$ ). 
According to the authors, the influence of the fertilization of this type of fertilization is justified by the decomposition and gradual release of the organic fertilizers, where, adequate nutrient contents, among them the nitrogen, favor the process of flowering and production of the Jatropha curcas (YONG et al., 2010).

The fruit dry weight variable (Figure $4 \mathrm{~B}$ and $\mathrm{C}$ ) presented a different trend in relation to the weight of the mature fruit, with a significant interaction with the cassava water, demonstrating an increase in the solids content of the fruit, positively influencing the productivity and commercialization of this oilseed. Thus, the highest value found was $89.04 \mathrm{~g}$, when cow urine was added within $0 \mathrm{ml}$ of the cassava syrup, presenting an increase of $82.01 \%$ in relation to the lowest value of $48.92 \mathrm{~g}$, obtained when used $250 \mathrm{~mL}$ of cow urine within $0 \mathrm{ml}$ of the syrup with cassava water.

A
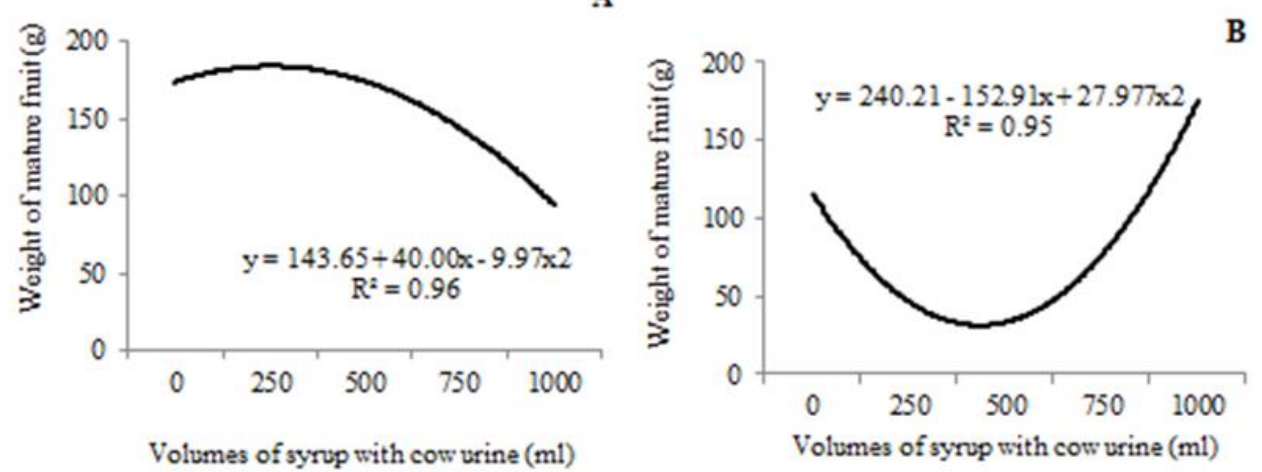

C
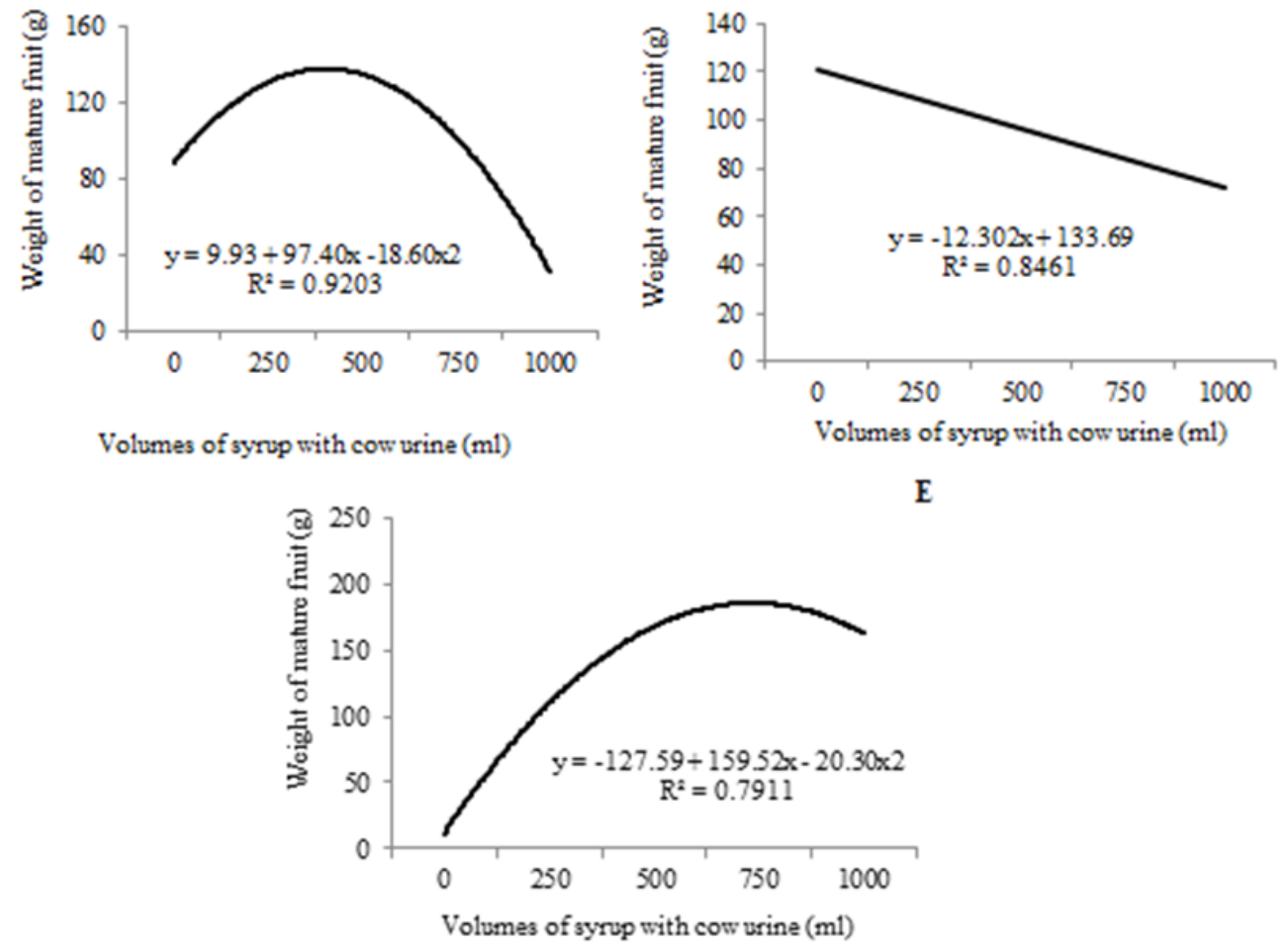

Figure 3. Regression analysis of the weight of mature fruits of jatropha during 360 days for interaction between cow urine within the volumes of 0.0 (A), $250 \mathrm{~mL}(\mathrm{~B}) ; 500 \mathrm{~mL}$ (C), $750 \mathrm{~mL}(\mathrm{D}), 1000 \mathrm{~mL}$ (E) of the syrup with the cassava water (p<0,05 and p<0,01). 

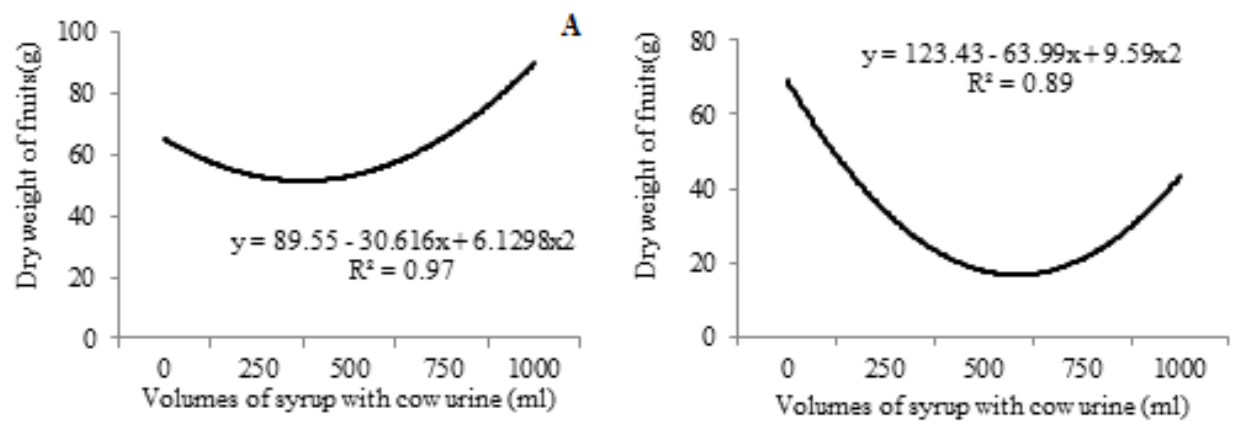

B
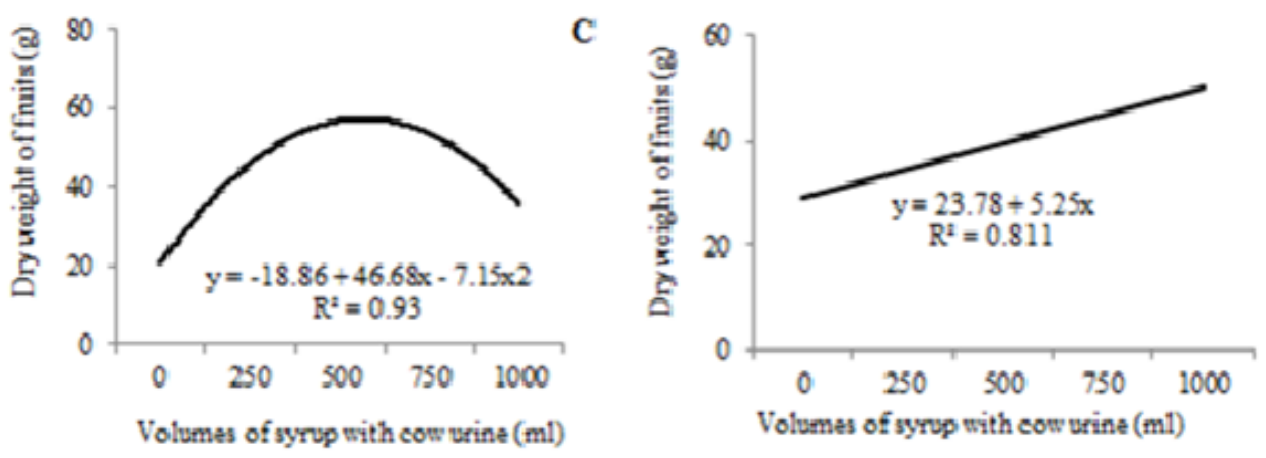

D

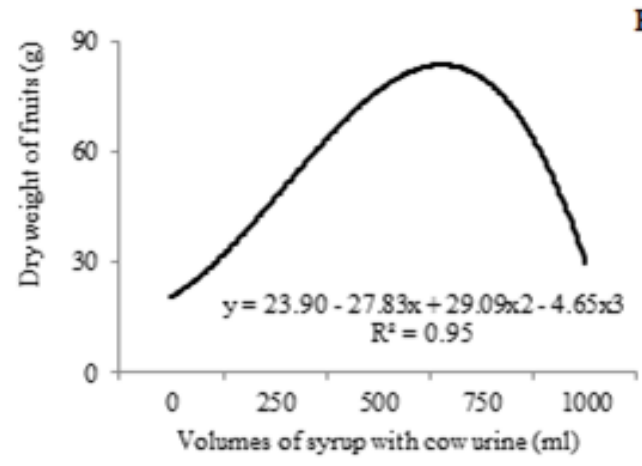

Figure 4. Regression analysis of dry weight of jatropha fruits, during 360 days, for interaction between cow urine within the volumes of 0,0 (A), $250 \mathrm{~mL}(\mathrm{~B}) ; 500 \mathrm{~mL}(\mathrm{C}), 750 \mathrm{~mL}$ (D), $1000 \mathrm{~mL}$ (E) of the syrup with the cassava water $(\mathrm{p}<0,05$ and $\mathrm{p}<0,01)$.

In the study of the regression analysis as a function of the addition of cow urine (CU), in the different volumes of the syrup with cassava water (MP), the variable, dry weight of the fruits had significant effects. In Figure 4D the trend line was linear, but in Figure 4E the trend line was cubic, but the best result was when $1000 \mathrm{ml}$ of the syrup was added with cow urine (CU) within $0 \mathrm{~mL}$ of the cassava water $(\mathrm{CW})$ syrup (Figure $4 \mathrm{~A})$.

Ferreira et al. (2011) declared that fertigation with cow urine and cassava water provided the best means for mass of the chapters, and that the dosage of $375 \mathrm{~mL}$ of cassava water provided higher sunflower productivity. However, Oliveira et al. (2012) affirm that the beet responds in growth to the application of solutions of cow's urine being the most pronounced effect when applied by soil, compared to the leaf.

\section{Conclusions}

Cow urine provides greater production of the Jatropha curcas, as well as heavier fruits when dry.

The interaction of cow urine with $500 \mathrm{~mL}$ of cassava water in syrup form provides a greater number of fruits.

The application of cow urine in $1,000 \mathrm{~mL}$ of cassava water provides a higher weight of mature fruits.

The dry weight of the fruits is not influenced by the interaction of cow urine with cassava water.

\section{References}

ALLEN, R. G.; PEREIRA, L. S.; RAES, D. Crop evapotranspiration: guidelines for computing crop water requirements. Rome: FAO, 1998. 300 p.

CELESTINO, R. C. A. Cow urine: efficient and cheap alternative. Rio de Janeiro-RJ: Editora PESAGRO, 2002. 8 p. 
CESAR, M. N. Z; PAULA, P. D. POLIDORO, J. C.; RIBEIRO, R. L. D.; PADOVAN, M. P. Stimulating effect of cow urine on the growth of cucumber seedlings, grown under organic management. Essay. Campo Grande-MS, v. 11, n. 1, p. $67-71,2007$.

DALLACORT, R.; MARTINS, J. A.; INOUE, M. H.; FREITAS, P. S. L.; KRAUSE, W. Agroclimatic fitness of the jatropha in the region of Tangará da Serra, MT. Journal of Science Agronomy, Fortaleza-CE, v. 41, n. 3, p. 373-379, 2010 .

DRUMOND, M. A.; SANTOS, C. A. F.; DE OLIVEIRA, V. R.; MARTINS, J. C.; ANJOS, J. B.; EVANGELISTA, M. R. $\mathrm{V}$. Agronomic performance of jatropha genotypes in the semiarid region of Pernambuco. Rural Science, Santa Maria-RS, v. 40, n. 1, p. $64-73,2010$.

EMBRAPA. BRAZILIAN COMPANY OF AGRICULTURAL RESEARCH. Brazilian system of soil classification. Rio de Janeiro-RJ: Embrapa Soils, 2013. 306 p.

FERNANDES, J. D.; CHAVES, L. H. G.; DANTAS, J. P.; SILVA, J. R. P.; Phenology and production of jatropha cultivated with different sources of fertilization. Journal of Science Agronomy, Fortaleza-CE, vol. 44, n. 2, p. 339-346, 2013.

FERREIRA, T. C.; SOUZA, J. T. A; ARAUJO, E. C. L.; SILVA, K.E. da; PEREIRA, C. G. OLIVEIRA, S. J. C. Accumulation of dried phytomass in sunflower (Helianthus annus L.) fertigated with cow urine and cassava. Journal of Agroecology, Porto Alegre-RS, v. 6, n. 2, p. 11-19, 2011.

FIORETTO, R. A. Direct use of cassava water in fertigation: management, use and treatment of byproducts of cassava industrialization. São Paulo-SP: Cargill Foundation, 2002. 48 p.

GARRONE, R. F.; CAMPOS, A. G.; SILVEIRA, C. P.; LAVRES JUNIOR, J. Production of biomass, nutritional diagnosis and absorption of nitrogen and calcium during initial growth of jatropha. Journal of Science Agronomy, FortalezaCE, v. 47, n. 1, p. 22-31, 2016.
MAGALHÃES, A. G.; ROLIM, M. M.; DUARTE, A. S.; BEZERRA NETO, E.; TABOSA, J. N.; PEDROSA, E. M. R. Initial development of maize submitted to fertilization with cassava water. Brazilian Journal of Agricultural and Environmental Engineering, Campina Grande-PB, v. 18, n. 7, p. 35-42, 2014.

NÁPOLES, F. A. M.; AZEVEDO, C. A. V.; SOUZA, J. T. A; SOUZA, G. A. V. S.; MONTENEGRO, F. T.; OLIVEIRA, S. J. C. Growth and production of Jatropha curcas L. as a function of organic fertilization. Agricultural Technology and Science Journal, João Pessoa-PB, v. 2, n. 10, p. 9-15, 2016.

OLIVEIRA, N. L. C.; PUIATTI, M.; BHERING, A. S.; CECON, P. R.; SILVA, G. C. C. Use of cow urine for table beet cultivation. Revista Brasileira de Agropecuária Sustentável, Viçosa-MG, v. 2, n. 2, p. 7-13, 2012.

OLIVEIRA, I. R. S.; OLIVEIRA, F.N.; MEDEIROS, M.A.; TORRES. S. B.; TEIXEIRA, F.J.V; Initial growth of jatropha (Jatropha curcas L.) as a function of the salinity of the irrigation water. Revista Caatinga, Mossoró-RN, v. 23, n. 4, p. $40-45,2010$.

PENMAN, H. L. Evaporation: an introductory survey. Netherlands Journal Agricultural Science, Cambridge, n. 4, p. $9-29,1956$.

SAS. STATISTICAL ANALYSIS SYSTEM, SAS/STAT 9.3

User's Guide. Cary, NC: SAS Institute Inc. 2011. 8621 p.

SARAIVA, Z. F.; SAMPAIO, C. S.; SILVESTRE, G. M.; QUEIROZ, M. F. M.; NOBREGA, H. P. L.; GOMES, M. B. Brazilian Journal of Agricultural and Environmental Engineering. Campina Grande-PB. v. 11, n. 1, p. 30-36, 2007.

YONG, J. W. H.; NG, Y. F.; TAN, S. N.; CHEW, A. Y. L. Effect of fertilizer application on photosynthesis and oil yield of Jatropha curcas L. Photosynthetica, Rozvojová, v. 48, n. 2, p. 208-218, 2010. 